\title{
PERSEPSI PERAWAT MENGENAI SPIRITUALITAS DAN PEMENUHAN KEBUTUHAN SPIRITUAL PASIEN DI INSTALASI GAWAT DARURAT
}

\author{
Ita Yuni Asih*, Dody Setyawan \\ Departemen Ilmu Keperawatan, Fakultas Kedokteran, Universitas Diponegoro, \\ Kota Semarang, 50275, Indonesia \\ *)E-mail: itayuniasih@yahoo.com
}

\begin{abstract}
ABSTRAK
Kepadatan pasien dan pergantian pasien yang cepat di Instalasi Gawat Darurat (IGD) menyebabkan perawat kurang optimal dalam memberikan asuhan keperawatan kebutuhan spiritual bagi pasien. Kondisi tersebut dapat mempengaruhi persepsi perawat IGD akan spiritualitas dan pemenuhan kebutuhan spiritual pasien. Pemenuhan kebutuhan spiritual pasien IGD yang baik juga dapat meningkatan hasil pengobatan yang baik. Perawat yang memiliki persepsi spiritual yang baik akan mempunyai kemampuan untuk memenuhi kebutuhan spiritual pasien. Tujuan: untuk mengetahui gambaran persepsi perawat mengenai spiritualitas dan pemenuhan kabutuhan spiritual pasien di IGD. Metode: penelitian ini menggunakan studi deskriptif survei. Sampel diambil menggunakan teknik total sampling dan diperoleh 75 responden. Data diambil dengan menggunakan kuesioner Spiritual Care-Giving Scale (SCGS) dan dianalisis dengan analisa univariat. Hasil penelitian: lebih dari separuh perawat IGD mempersepsikan kebutuhan spiritual dan pemenuhan kebutuhan spiritual pasien sebagai hal yang sangat penting (57,3\%). Setiap aspek juga dipersepsikan sangat penting oleh perawat IGD, yaitu atribut dalam pemenuhan kebutuhan spiritual (77,3\%), perspektif kebutuhan spiritual (60\%), gambaran pemenuhan kebutuhan spiritual (54,7\%), sikap dalam pemenuhan kebutuhan spiritual (88\%), dan nilai-nilai dalam pemenuhan kebutuhan spiritual $(65,3 \%)$. Kesimpulan: aspek yang perlu diperbaiki adalah nilai-nilai dalam pemenuhan kebutuhan spiritual. Nilai-nilai dari spiritualitas diartikan sebagai bagian dari keperawatan holistik yang sangat penting. Oleh karena itu, perawat IGD perlu meningkatkan pemahaman tentang spiritualitas agar implementasi pemenuhan kebutuhan spiritual pasien di IGD dapat positif diperkuat.
\end{abstract}

Kata kunci: perawat gawat darurat, persepsi, spiritual

\section{Nurses' Perception of Spirituality and Fulfill the Spiritual Needs of Patients in the Emergency Department}

\section{ABSTRACT}

Patient overcrowding and rapid patient turnover in emergency department cause nurses to be less than optimal in providing patients spiritual needs. This condition can affect the emergency nurses'perceptions of spirituality and fulfill the patient's spiritual needs. A good fulfillment of the emergency patients spiritual needs can also improved a good treatment results. Nurses who have a good spiritual perception will have the ability to fulfill the patient's spiritual needs. Objective: describe nurses' perception of spirituality and fulfill the spiritual needs of patients in the emergency department. Methods: This study was used descriptive survey research. Samples were taken using total sampling technique and obtained 75 participants. Data were taken using the Spiritual Care Giving Scale (SCGS) questionnaire and analyzed by univariate analysis. Results: more than a half of emergency nurses considered spiritual needs and fulfilled the patient's spiritual needs as very important (57,3\%). Every aspects is also perceived to be very important by emergency nurses, that is attributes in meeting spiritual needs (77.3\%), perspective of spiritual needs (60\%), description of meeting spiritual needs (54.7\%), attitudes in meeting spiritual needs (88\%), and values in meeting spiritual needs (65.3\%). Conclusion: An aspect that need to be improved are values in fulfilling spiritual needs. The value of spirituality is interpreted as a very important part of holistic nursing. Consequently, emergency nurses need to improve their understanding of spirituality so that the implementation of fulfilling patients spiritual needs in emergency department can be positively reinforced.

Keywords: emergency nurse, perception, spiritual 


\section{LATAR BELAKANG}

Instalasi Gawat Darurat (IGD) merupakan gerbang utama masuknya pasien gawat darurat (Sondakh, Bidjuni, \& Malara, 2017). Pelayanan pasien gawat darurat memegang peranan yang sangat penting dimana waktu adalah nyawa (Time saving is life saving). Pasien di IGD memerlukan pelayanan yang harus dilakukan segera yaitu cepat, tepat, dan cermat untuk mencegah kematian dan kecacatan (Fadhilah, Harahap, \& Lestari, 2013). Kepadatan pasien dan pergantian pasien yang cepat di IGD membuat perawat mengalami kesulitan dalam pemenuhan aspek spiritual pasien (Ziel \& Kautz, 2009).

Spiritualitas adalah komponen penting dari kesehatan pasien. Kebutuhan spiritual pasien IGD yang tidak terpenuhi dapat beresiko mengakibatkan hasil pengobatan yang kurang baik. Hal ini disebabkan pasien mengalami depresi, stress, kemarahan, dan emosi yang negatif (Mdiv, dkk, 2016). Di IGD pasien mengalami ketakutan yang besar, trauma, dan menjadi negatif secara spiritual. Oleh karena itu, pasien membutuhkan pemenuhan kebutuhan spiritual karena dapat memberikan efek positif pada respon stress individu (Mdiv dkk, 2016). Akan tetapi, sebelum memberikan asuhan keperawatan tentang spiritualitas secara menyeluruh dan komprehensif perawat harus memiliki persepsi akan spiritualitas (Hwa, Creedy, \& Fai, 2013).

Kemampuan perawat dalam memberikan asuhan spiritual dipengaruhi oleh persepsi perawat tentang spiritualitas dan perawatan spiritual (Melhem, dkk, 2016). Persepsi perawat sendiri dapat dipengaruhi oleh beberapa faktor, yaitu latar belakang budaya, agama, tingkat pendidikan, dan pengalaman klinis dari perawat (Ozbasaran, dkk, 2011). Selain itu area bekerja dan spesialis keperawatan yang berbeda juga memiliki perbedaan persepsi tentang spiritualitas dan perawatan spiritual (Melhem, dkk, 2016).
Perawat IGD memiliki persepsi yang positif dan pemahaman yang baik tentang spiritualitas dan perawatan spiritual, akan tetapi ada beberapa hambatan yang dihadapi yaitu kecukupan waktu dan kontak yang terbatas dengan pasien (Yingting, dkk, 2018). Perawat IGD mengalami kesulitan dalam mengkaji kebutuhan spiritual pasien karena kekurangan waktu dan adanya pergantian pasien dengan cepat (Ronaldson, dkk, 2012). Hal tersebut menjadikan perawat IGD memiliki pandangan bahwa mengelola penyakit yang mengancam jiwa harus lebih diutamakan dari pada memenuhi kebutuhan spiritual pasien (Nixon, Narayanasamy, \& Penny, 2013).

Studi pendahuluan pada lima perawat IGD di salah satu rumah sakit kota Semarang didapatkan bahwa perawat mempersepsikan spiritual secara berbeda-beda. Sebanyak tiga perawat mengatakan bahwa spiritual adalah sesuatu yang berhubungan dengan rohani dan merupakan suatu kebutuhan untuk mendekatkan diri kepada Tuhan. Dua perawat mengartikan spiritual sebagai hal yang sama dengan religi. Hambatan yang dihadapi perawat dalam pemenuhan kebutuhan spiritual adalah kepadatan pasien di IGD. Perawat tidak bisa fokus terhadap satu pasien dan memerlukan banyak waktu untuk memenuhi kebutuhan fisik pasien yang gawat darurat. Berdasarkan hal tersebut maka perlu dilakukan penelitian tentang gambaran persepsi perawat mengenai spiritualitas dan pemenuhan kebutuhan spiritual pasien di Instalasi Gawat Darurat.

\section{METODE}

Desain penelitian ini adalah deskriptif survei. Teknik sampling yang digunakan adalah total sampling dengan besar sampel 75 orang perawat di IGD salah satu rumah sakit kota Semarang. Penelitian dilaksanakan September 2018-Juni 2019. Instrumen yang digunakan adalah kuesioner 
data demografi dan Kuesioner Spiritual Care-Giving Scale (SCGS). Kuesioner SCGS merupakan kuesioner tertutup berisi total 35 pernyataan yang terdiri dari 5 komponen, diantaranya atribut dalam pemenuhan kebutuhan spiritual (8 item), perspektif kebutuhan spiritual (8 item), gambaran pemenuhan kebutuhan spiritual (7 item), sikap dalam pemenuhan kebutuhan spiritual (7 item), dan nilai-nilai dalam pemenuhan kebutuhan spiritual (5 item).

Kuesioner sudah dilakukan uji validitas pada penelitian sebelumnya dengan hasil $r$ hitung $(0,427-0,882)>r$ tabel $(0,361)$ dan uji reliabilitas dengan nilai Cronbach alpha $0.97(>0,60)$ yang berarti kuesioner valid dan reliabel (Purwatisari, 2015). Data yang diperoleh dilakukan uji normalitas data menggunakan uji test of normality Kolmogorov-Smirnov. Data yang diperoleh diketahui terdistribusi tidak normal dengan nilai $p=0,000(p<0,05)$, nilai mean 146,85 dan nilai median 143. Oleh karena itu pengkategorian persepsi perawat mengenai spiritualitas dan pemenuhan kebutuhan spiritual pasien menggunakan nilai median, yaitu sangat penting jika skor $\geq 143$ dan kurang penting jika skor $<143$. Data dianalisis secara univariat, serta disajikan dalam bentuk tabel distribusi frekuensi.

\section{HASIL}

Tabel 1. Distribusi Frekuensi

Responden Berdasarkan Karakteristik

Responden di Instalasi Gawat Darurat

Bulan Mei Tahun $2019(n=75)$

\begin{tabular}{lcc}
\hline $\begin{array}{c}\text { Kategori } \\
\text { Responden }\end{array}$ & Frekuensi & $\begin{array}{c}\text { Persentase } \\
\text { (\%) }\end{array}$ \\
\hline Jenis Kelamin & & \\
Laki-laki & 34 & $45,3 \%$ \\
Perempuan & 41 & $54,7 \%$ \\
\hline
\end{tabular}

\begin{tabular}{lcc}
\hline \multicolumn{1}{c}{$\begin{array}{c}\text { Kategori } \\
\text { Responden }\end{array}$} & Frekuensi & $\begin{array}{c}\text { Persentase } \\
\mathbf{( \% )}\end{array}$ \\
\hline Usia & & \\
26-35 tahun & 58 & $77,3 \%$ \\
36-45 tahun & 10 & $13,4 \%$ \\
46-55 tahun & 7 & $9,3 \%$ \\
Lama bekerja di & & \\
IGD & 20 & $26,7 \%$ \\
$<5$ tahun & 34 & $45,3 \%$ \\
tahun & 21 & $28,0 \%$ \\
$>10$ tahun & & \\
& & \\
Kewenangan klinis & & \\
Pra perawat klinis & 2 & $2,7 \%$ \\
Perawat Klinis 1 & 5 & $6,7 \%$ \\
Perawat Klinis 2 & 44 & $58,8 \%$ \\
Perawat Klinis 3 & 20 & $26,7 \%$ \\
Perawat Klinis 4 & 4 & $5,3 \%$ \\
Tingkat Pendidikan & & \\
D III & 50 & $66,7 \%$ \\
D IV & 3 & $4,0 \%$ \\
S1/ Ners & 20 & $26,8 \%$ \\
S2 & 2 & $2,7 \%$ \\
\hline Total & 75 & $100 \%$ \\
\hline
\end{tabular}

Sebanyak total sampel 75 responden telah dianalisis dan didapatkan hasil sesuai tabel 1, antara lain lebih dari separuh responden yaitu sejumlah $54,7 \%$ berjenis kelamin perempuan. Sebanyak $77,3 \%$ berada pada rentang usia 26-35 tahun dan mayoritas responden bekerja di IGD selama rentang waktu 5 sampai dengan 10 tahun yaitu sebanyak $45,3 \%$. Lebih dari separuh responden, yaitu sebanyak $58,7 \%$ memiliki jenjang karir perawat klinik 2, dan memiliki tingkat pendidikan Diploma 3 (D3), yaitu sejumlah $66,7 \%$ responden. 
Tabel 2. Distribusi Frekuensi Persepsi

Responden Mengenai Spiritualitas dan Pemenuhan Kebutuhan Spiritual Pasien IGD Bulan Mei Tahun 2019 ( $n=75)$

\begin{tabular}{|c|c|c|c|}
\hline No. & Kategori & Frekuensi & $\begin{array}{c}\text { Persentase } \\
(\%)\end{array}$ \\
\hline 1. & $\begin{array}{l}\text { Sangat } \\
\text { Penting }\end{array}$ & 43 & $57,3 \%$ \\
\hline 2. & $\begin{array}{l}\text { Kurang } \\
\text { Penting }\end{array}$ & 32 & $42,7 \%$ \\
\hline & Total & 75 & $100 \%$ \\
\hline
\end{tabular}

Dari Tabel 2 diketahui bahwa lebih dari setengah responden mempersepsikan spiritualitas dan pemenuhan kebutuhan spiritual pasien IGD merupakan hal yang sangat penting. Dari Tabel 3 diketahui bahwa atribut dalam pemenuhan kebutuhan spritiual dan sikap dalam pemenuhan kebutuhan spiritual dipersepsikan sebagai sangat penting oleh lebih dari tiga perempat responden $(77,3 \%$ dan $88 \%)$, perspektif kebutuhan spritual, gambaran pemenuhan kebutuhan spiritual, dan nilainilai dalam pemenuhan kebutuhan spiritual dipersepsikan sangat penting oleh lebih dari setengah responden $(60 \%, 54,7 \%$, dan $65,3 \%)$.

Tabel 3. Distribusi Frekuensi Berdasarkan Komponen Persepsi Perawat Mengenai Spiritualitas dan Pemenuhan Kebutuhan Spiritual Pasien IGD Bulan Mei Tahun 2019 (n=75)

\begin{tabular}{|c|c|c|c|}
\hline No. & Kategori & Frekuensi & Persentase (\%) \\
\hline \multirow[t]{4}{*}{1.} & Atribut dalam pemenuhan kebutuhan spiritual & & \\
\hline & Sangat penting & 58 & $77,3 \%$ \\
\hline & Kurang penting & 17 & $22,7 \%$ \\
\hline & Perspektif kebutuhan spiritual & & \\
\hline \multirow[t]{3}{*}{2.} & Sangat penting & 45 & $60 \%$ \\
\hline & Kurang penting & 30 & $40 \%$ \\
\hline & Gambaran pemenuhan kebutuhan spiritual & & \\
\hline \multirow[t]{3}{*}{3.} & Sangat penting & 41 & $54,7 \%$ \\
\hline & Kurang penting & 34 & $45,3 \%$ \\
\hline & Sikap dalam pemenuhan kebutuhan spiritual & & \\
\hline \multirow[t]{3}{*}{4.} & Sangat penting & 66 & $88 \%$ \\
\hline & Kurang penting & 9 & $12 \%$ \\
\hline & Nilai-nilai dalam pemenuhan kebutuhan spiritual & & \\
\hline \multirow[t]{2}{*}{5.} & Sangat penting & 49 & $65,3 \%$ \\
\hline & Kurang penting & 26 & $34,7 \%$ \\
\hline \multicolumn{2}{|l|}{ Total } & 75 & $100 \%$ \\
\hline
\end{tabular}




\section{DISKUSI}

\section{Karakteristik Responden}

Pada penelitian ini diperoleh data bahwa jumlah perawat perempuan lebih banyak dari pada laki-laki. Perawat identik dengan seorang perempuan sampai saat ini, walaupun laki-laki juga mampu berprofesi sebagai seorang perawat dan mempunyai hak yang sama (Sutria, dkk, 2017). Perempuan lebih dikenal sebagai sosok yang memiliki sifat kelembutan, memiliki kemampuan komunikasi yang lebih menarik dari pada laki-laki, lebih mudah berempati dengan orang lain, dan keibuan.

Usia responden pada penelitian ini mayoritas berada pada usia dewasa awal (26-35 tahun). Syarat pendaftaran perawat saat masuk rumah sakit yaitu usia minimal 20 sampai dengan 35 tahun. Sebelum ditempatkan di IGD, perawat harus memiliki sertifikat khusus keterampilan menjadi perawat IGD, memiliki pengalaman klinis minimal 2 tahun, dan memiliki pendidikan setingkat D3 (Menteri Kesehatan Republik Indonesia, 2018).

Hasil penelitian menunjukkan bahwa lebih dari separuh jumlah perawat memiliki jenjang karir Perawat Klinik 2 (PK2). Hal ini karena sebagian besar perawat IGD memiliki masa kerja di IGD 5-10 tahun. Untuk menjadi Perawat Klinik 1 (PK1) harus ditempuh selama 2 tahun dan setelah 3 tahun perawat dapat mengajukan uji kompetensi untuk menjadi PK2 (Ardani \& Kurniastanti, 2016). Dengan demikian maka masa kerja minimal perawat IGD dengan kriteria PK2 adalah 5 tahun.

Penelitian ini menemukan bahwa sebagian besar perawat IGD mempunyai tingkat pendidikan Diploma 3 (D3). Data yang didapatkan dari Kemenkes RI juga menemukan bahwa perawat dengan pendidikan D3 merupakan mayoritas dari perawat Indonesia (Kementerian Kesehatan
Republik Indonesia, 2009). Hal ini sesuai dengan data yang didapatkan bahwa pada tahun 2018 pihak rumah sakit merekrut 100 perawat lulusan D3 dan tidak ada formasi untuk merekrut perawat lulusan Sarjana.

\section{Persepsi Perawat Mengenai Kebutuhan Spiritual dan Pemenuhan Kebutuhan Spiritual Pasien.}

Penelitian ini menunjukkan bahwa perawat IGD mempunyai persepsi yang baik tentang spiritual dan pemenuhan kebutuhan spiritual pasien. Lebih dari separuh perawat IGD mempersepsikan spiritualitas dan pemenuhan kebutuhan spiritual sebagai hal yang sangat penting. Perawat IGD mempunyai perilaku yang positif dan pemahaman yang baik tentang spiritualitas dan perawatan spiritual (Yingting, dkk, 2018). Perawat sadar bahwa spiritualitas membantu pasien untuk menemukan arti dalam kehidupannya dan mampu meningkatkan dukungan dalam situasi yang dihadapi di IGD. Perawat IGD memahami bahwa memenuhi kebutuhan spiritual merupakan bagian integral dari perawatan holistik (Rogers \& Wattis, 2015). Hal tersebut menjadi sangat penting karena pasien IGD datang dalam kondisi cemas, takut dan stress. Mereka membutuhkan pemenuhan kebutuhan spiritual karena akan memberikan dampak positif pada respon stress dan berpengaruh terhadap kondisi kesehatannya (Momennasab, Moattari, \& Shamishiri, 2012).

Meskipun demikian $42,7 \%$ perawat IGD mempersepsikan kebutuhan spiritual dan pemenuhan kebutuhan spiritual kurang penting. Ini tidak jauh berbeda dengan perawat yang mempunyai persepsi sangat penting. Hal ini karena beban kerja mereka yang terlalu tinggi, keterbatasan waktu, dan kurangnya pendidikan perawat akan spiritual sehingga membuat perawat IGD sulit untuk memenuhi kebutuhan spiritual 
pasien (McBrien, 2010). Demikian pula dengan penelitian yang dilakukan kepada perawat IGD di Amerika. Perawat IGD lebih mengutamakan kebutuhan fisik yang gawat darurat, dan merasa bahwa memenuhi kebutuhan spiritual lebih pantas dilakukan setelah fase akut terlewati (Nixon, dkk., 2013).

Pada komponen pertama, sebagian besar perawat IGD mempersepsikan atribut dalam pemenuhan kebutuhan spiritual sebagai hal yang sangat penting. Sebagian besar perawat IGD setuju dan sangat setuju dengan pernyataan perawat yang memiliki kesadaran spiritual mempunyai kemungkinan yang lebih untuk bisa memberikan asuhan keperawatan spiritual pada pasien. Hal ini sesuai dengan penelitian yang dilakukan kepada perawat di Turki yang menemukan bahwa perawat yang memiliki kesadaran spiritual yang tinggi lebih memahami, peka, dan mahir dalam pemenuhan kebutuhan spiritual pasien (Ozbasaran dkk., 2011). Perawat akan sulit mengenali kebutuhan spiritual pasien dalam menangani kondisi di IGD yang padat, dalam hal ini kesadaran perawat dalam mengenali dan memahami kebutuhan spiritual pasien sangat dibutuhkan karena tanpa kesadaran spiritual, asuhan keperawatan spiritual sulit untuk diberikan.

Pada komponen kedua, lebih dari separuh perawat IGD mempersepsikan perspektif kebutuhan spiritual sebagai hal yang sangat penting. Namun, sebagian kecil perawat IGD kurang setuju dan tidak setuju dengan pernyataan spiritualitas adalah ekspresi perasaan batin seseorang yang mempengaruhi perilakunya. Spiritualitas adalah bentuk dari energi seseorang yang dapat mempengaruhi perasaan dan emosi. Perasaan dan emosi itu sendiri dapat diamati dalam bentuk perilaku seseorang (Cameron \& Spreitzer, 2012). Perawat yang memperhatikan spiritualitas diri mereka sendiri mempunyai perasaan batin yang baik. Perawat yang kurang dan tidak setuju dengan pernyataan tersebut bisa terjadi karena perawat tidak memahami akan pengertian dari spiritualitas itu sendiri.

Pada komponen ketiga, lebih dari separuh perawat IGD mempersepsikan gambaran pemenuhan kebutuhan spiritual sebagai hal yang sangat penting. Namun, Sebagian kecil perawat IGD kurang dan tidak setuju dengan pernyataan berada bersama pasien merupakan suatu bentuk pemenuhan kebutuhan spiritual pasien. Pernyataan ini sesuai dengan sebuah penelitian kepada perawat IGD di Irlandia. Perawat IGD mengesampingkan kebutuhan spiritual karena terdapat hambatan fisik, terlalu sibuk, dan keterbatasan waktu saat menangani pasien gawat darurat (McBrien, 2010). Hal ini dikarenakan beban kerja perawat IGD yang tinggi dan kurangnya waktu perawat dalam memenuhi kebutuhan spiritual. Mereka disibukkan dengan pemenuhan kebutuhan fisik yang lebih mengancam jiwa pasien, sehingga waktu untuk berada bersama pasien merupakan hal yang sulit untuk sebagian perawat IGD.

Pada komponen keempat, sebagian besar perawat IGD mempersepsikan sikap dalam pemenuhan kebutuhan spiritual sebagai hal yang sangat penting. Sebagian besar perawat IGD setuju dan sangat setuju dengan pernyataan pemenuhan kebutuhan spiritual harus ditanamkan di seluruh program pendidikan keperawatan. Perawatan spiritual yang terintegrasi kedalam program pendidikan keperawatan merupakan kebutuhan perawat. Menanamkan spiritualitas ke dalam program pendidikan keperawatan direkomendasikan untuk meningkatkan pengetahuan dan keterampilan perawat dalam menangani masalah spiritual (Melhem, dkk, 2016).

Pada komponen kelima, sebagian besar perawat IGD mempersepsikan nilai- 
nilai dalam pemenuhan kebutuhan spiritual sebagai hal yang sangat penting. Sebagian besar perawat IGD setuju dan sangat setuju dengan pernyataan pemenuhan kebutuhan spiritual pasien merupakan komponen integral dalam perawatan holistik. Manusia adalah makhluk holistik yang terdiri dari 3 komponen yaitu body, mind, dan, spirit. Manusia merupakan makhluk unik yang utuh menyeluruh yang meliputi aspek fisik, psikologis, sosial, kultural, dan spiritual. Tidak terpenuhinya salah satu aspek tersebut dapat mengakibatkan pasien IGD mengalami ketidaksejahteraan (Nixon, dkk, 2013). Spiritualitas adalah komponen penting dalam kesehatan pasien. Seseorang yang sehat secara spiritual biasanya mampu mengatasi kesulitan dan kehilangan, memiliki kualitas hidup yang baik, dan kemungkinan depresi yang rendah (Yingting dkk, 2018).

Penelitian yang dilakukan masih banyak memiliki keterbatasan yang dapat memengaruhi hasil penelitian. Saat pengambilan data penelitian tidak semua perawat dapat ditemui saat konferen pagi, sehingga peneliti menemui perawat IGD saat pergantian shift. Beberapa perawat dalam mengisi kuesioner dalam kondisi terburuburu karena harus melakukan operan jaga bagi yang baru datang dan ingin segera pulang bagi yang sudah selesai bekerja.

\section{SIMPULAN}

Perawat memiliki persepsi yang positif tentang spiritualitas dan pemenuhan kebutuhan spiritual. Lebih dari separuh perawat IGD mempersepsikan spiritualitas dan pemenuhan kebutuhan spiritual sebagai hal yang sangat penting. Setiap komponen dalam pemenuhan kebutuhan spiritual juga dipersepsikan perawat sebagai hal yang sangat penting.

Hasil penelitian ini menunjukkan bahwa perawat IGD harus lebih meningkatkan lagi sikap dan pemahaman tentang nilai-nilai dalam pemenuhan kebutuhan spiritual pasien. Perawatan spiritual dapat diperkuat secara positif dengan cara diskusi mendalam dalam kegiatan klinis di rumah sakit atau dengan pelatihan dan seminar. Kesulitan atau kekurangan yang dihadapi saat pemberian asuhan spiritual diharapkan dapat selalu dilakukan evaluasi dan perbaikan sehingga mutu pelayanan dapat ditingkatkan.

\section{DAFTAR PUSTAKA}

Ardani, M. H., \& Kurniastanti, R. M. (2016). Pelaksanaan pengembangan jenjang karir perawat di rumah sakit. M.Med. Mud, 1, 109-114.

Cameron, K. S., \& Spreitzer, G. M. (2012). The oxford handbook of positive organizational scholarship. New York: Oxford University Press, Inc.

Fadhilah, N., Harahap, W. A., \& Lestari, Y. (2013). Faktor-faktor yang berhubungan dengan waktu tanggap pada pelayanan kasus kecelakaan lalu intas di instalasi gawat darurat rumah sakit umum pusat dr. M. djamil, Jurnal Kesehatan Andalas, 4(1), 195-201.

Hwa, L., Creedy, D. K., \& Fai, M. (2013). Nurse education today student nurses ' perspectives of spirituality and spiritual care. YNEDT, 33(6), 574-579. https://doi.org/10.1016/j. nedt.2012.06.007

Kementerian Kesehatan Republik Indonesia. (2009). Standar instalasi gawat darurat (IGD) rumah sakit. Retrieved from https://sardjito. co.id/sardjitowp/wp-content/ uploads/2015/12/kepmenkes-856thn-2009-standar-IGD.pdf

McBrien, B. (2010). Nurses' provision of spiritual care in the emergency setting-an Irish Perspective. 
IEN, 18(3), 119-126. https://doi. org/10.1016/j.ienj.2009.09.004

Mdiv, M. B., French, A., Martin, M. L., \& Sarvaananda, S. (2016). Spiritual care services in emergency medicine. In M. L. Martin, S. Heron, \& L. M. Walton (Eds.), Diversity and inclusion in quality patient care (pp. 83-100). New York: Springer, Cham. https://doi.org/https://doi. org/10.1007/978-3-319-22840-2_8

Melhem, G. A., Zeilani, R. S., Zaqqout, O. A., Aljwad, A. I., Shawagfeh, M. Q., \& Al Rahim, M. A. (2016). Nurses' perceptions of spirituality and spiritual care giving: a comparison study among all health care sectors in jordan. Indian $J$ Palliat Care, 1, 42-49. https://doi. org/10.4103/0973-1075.173949

Menteri Kesehatan Republik Indonesia. (2018). Peraturan menteri kesehatan republik indonesia nomor 47 tahun 2018 tentang pelayanan gawat darurat. Retrieved from http://www.depkes.go.id/resources/ download/peraturan/PMK No. 47 Th 2018 ttg Pelayanan Kegawatdaruratan.pdf

Momennasab, M., Moattari, M., \& Shamishiri, B. (2012). Spirituality in survivors of myocardial infarction. Iranian Journal of Nursing and Midwifery Research, 17(5), 343351.

Nixon, A. V., Narayanasamy, A., \& Penny, V. (2013). An investigation into the spiritual needs of neuro-oncology patients from a nurse perspective. BMC Nursing, 12(1), 1. https://doi. org/10.1186/1472-6955-12-2

Ozbasaran, F., Ergul, S., Temel, A. B., Aslan, G. G., \& Coban, A. (2011). Turkish nurses' perceptions of spirituality and spiritual care. J Clin Nurs,
3102-3110. https://doi.org/10.1111/ j.1365-2702.2011.03778.x

Purwatisari. (2015). Gambaran persepsi perawat mengenai kebutuhan spiritual dan pemenuhan kebutuhan spiritual pasien kanker di rsud tugurejo semarang (Skripsi). Universitas Diponegoro, Semarang, Indonesia.

Rogers, M., \& Wattis, J. (2015). Spirituality in nursing practice. Rcni, 29(39), $51-57$.

Ronaldson, S., Hayes, L., Aggar, C., Green, J., \& Carey, M. (2012). Spirituality and spiritual caring: Nurses' perspectives and practice in palliative and acute care environments. J Clin Nurs, 21(15-16), 2126-2135. https://doi.org/10.1111/j.13652702.2012.04180.x

Sondakh, N. A., Bidjuni, H., \& Malara, R. T. (2017). Hubungan tingkat kegawatan dengan lama tinggal pasien di IGD RSU gmim kalooran amurang. EKp, 5.

Sutria, E., Ashar, M. U., Kerja, L., \& Caring, P. (2017). Faktor-faktor yang berhubungan dengan perilaku caring perawat di ruang perawatan interna. JOIN, 2(2), 83-92.

Yingting, Z., Pal, R. Y., Wilson, T. W. S., Lee, A., Ong, M., \& Tiew, L. H. (2018). Spiritual perspectives of emergency medicine doctors and nurses in caring for end-of-life patients: A mixed-method study. IEN, 37, 13-22. https://doi.org/10.1016/j. ienj.2017.07.001

Ziel, R., \& Kautz, D. D. (2009). The highest priority in the emergency department may be a patient's spiritual needs. $J$. Emerg. Nurs, 35(1), 50-51. https:// doi.org/10.1016/j.jen.2008.09.005 